\title{
Poetry AfTer Libricide ANd Genocide
}

CHERAN RUDHRAMOORTHY

University of Windsor, Ontario cheran@uwindsor.ca

Received: 17-09-2015

Accepted: 31-01-2016

Where they have burned books, they will end in burning human beings

- Heinrich Heine ${ }^{1}$

\section{The Second Sunrise and the Poetics of Libricide}

Thirty years ago, after witnessing the burning of Jaffna town and its reputed public library by the Sri Lankan security forces, I wrote a poem titled irandaavathu sooriya uthayam ("The Second Sunrise"). ${ }^{2}$ The title was an obvious reference to the libricide ${ }^{3}$ committed by the Sri Lankan state forces. It was also the title of my first anthology of poems. I was an undergraduate student at the university of Jaffna and active in student politics then. A group of my friends and I were staying at the fifth floor of the Balasingham Hostel for men located a short distance from the main buildings of the university. It was sunset and we could see heavy smoke billowing from the direction of Jaffna town centre. Initially, we had no idea of what was burning. Then the story spread

\footnotetext{
${ }^{1}$ Almansor: A Tragedy (1823), as translated in True Religion (2003) by Ward, 2003:142.

${ }^{2}$ English translation of the poem appears in, You Cannot Turn Away, Poems by Cheran, translated and edited by Chelva Kanaganayakam. Toronto: TSAR Publishers, 2011 and The Second Sunrise Cheran's Poems, translated and edited by Lakshmi Holmström and Sascha Ebeling, New Delhi: Navayana, 2012.

${ }^{3}$ Rebecca Knuth's book, Libricide: The Regime Sponsored Destruction of Books and Libraries in the Twentieth Century (Praeger: 2003) uses the term to describe ideologically driven and systemic destruction of books and libraries that paralleled acts of genocide in the 20th century.
} 
like another fire: the entire Jaffna town including the library and the offices of the Tamil daily Eelanadu had been set on fire. We rushed to the town but could not make much headway because of the presence of state security forces. By the time we managed to reach the library, in the morning, the burning was complete. The historic edifice with 97,000 books, invaluable old manuscripts and archival material was in ashes. Father David, a polyglot, an ardent lover of the Jaffna public library and a great man of letters saw the burning of the library from the second floor of the Jaffna Bishop's House and died of a heart attack. We saw hundreds and hundreds of people walking toward the library from all directions in shock. Sri Lankan security forces that were brought specifically for the "assignment" from southern Sri Lanka were stationed next to the library in the Thuraiappah stadium. Several of them were standing on the pavilion seats and taunted us:

“Oh poor souls, don't cry, don't' cry! All is gone? Right?"

Then they stared laughing at the people and began dancing to the tune of Baila-a popular Sinhala music of Portuguese origins. I had no inkling that celebrating the destruction of a cultural icon then was a harbinger of events to come in the next thirty years.

I vividly remember that day. We were helpless and angry. Thousands of us were mourning the deliberate destruction of a cultural symbol and the repository of knowledge while the very forces responsible for the carnage were celebrating our tears and sorrow. The air was filled with lament and curses. I recall seeing a middle aged woman throwing a handful of sand at the state forces and cursing them loudly.

I had been very attached to the library for a long time. When I was a child, my father, a senior Sri Lankan government civil servant, would drop me off at the library's children section every Saturday morning. As the District Land Officer (DLO) in the government secretariat he always worked on Saturdays. He would pick me up later in the afternoon. Since I was an avid reader, I thoroughly enjoyed the time there and the library became 212

Indi@logs, Vol 3 2016,pp.211-228, ISSN 2339-8523 
my second home. After I grew up I discovered the library auditorium as the place for writers, journalists and poets to gather for book launches and literary meetings. I still remember the fight I had with the library authorities in the mid seventies. People who did not live within the municipal limits of Jaffna were not allowed to borrow books. As I was from a village ten miles from the Jaffna town I was ineligible to borrow books and I protested. Eventually, a compromise was reached and I gave them the address of one of my relatives who lived in the town area and became a member. I kept my library card until we were forced to leave our home by the army in 1992 and the subsequent occupation of our village and hundreds of others.

The burning of the library, hundreds of shops, the Eelanadu daily newspaper's office and press, and the office of the Tamils United Liberation Front (TULF) was perhaps the public, political, cultural and violent articulation of difference by the State. In two other symbolic acts of violence, the forces had broken the statues of great Tamil poets Thiruvalluvar and Avvaiyar in the Jaffna town on the same night. Whether the forces knew the importance of the statues was not clear. However, the statues might have been perceived as culturally important for the "Other" and therefore breaking them up was a necessary violent act of re-inscribing the differences. The other act was the demolition of the memorial for the 11 people killed in the final day of the International Tamil Research Conference held in Jaffna in 1974. Commemorating and celebrating our "own" while destroying and eliminating the "other" is a pervasive logic of genocide that was frequently deployed by the state. ${ }^{4}$

In addition to the political and cultural significance these were also acts of revenge and retaliation to the killing of two policemen at an election rally by Tamil militants. It was

\footnotetext{
${ }^{4}$ Anthropologist Michael Roberts, in his essay (Nethra,1993) on the July 1983 pogrom against Tamils, "Agony and Ecstasy" describes the celebratory attitude of the Sinhala goons that were killing Tamils. On December 3, 1984, as a journalist working for the Jaffna-based English language weekly Saturday Review, I interviewed several survivors of a massacre at Othiyamalai in the Vanni. 32 men were massacred by the Sri Lankan army. The survivors described how after killing the victims one by one the army loaded the bodies on to tractors and sped off while singing and dancing. After the war, the security forces have systematically erased all the monuments and cemeteries called maaveerar illam (Great Heroes Cemetery) constructed by the Tigers in the North and East while building numerous monuments to commemorate the fallen Sinhala soldiers. The people in the North and East are not even permitted to remember and commemorate their dead.
} 
widely reported that two senior ministers of the then United National Party (UNP) government, Gamini Dissanayake and Cyril Mathew were present in Jaffna when the city was burned.

We returned to the Jaffna University students' council room after spending several hours in the Jaffna town. An emergency council meeting ensued. For the whole of next week hundreds of us did not attend classes - opting instead to travel village by village with the message that the time for our national liberation struggle had come. Eelanadu was the only Tamil daily newspaper published in Jaffna at that time. Since its office had been burnt down, there was no longer any reliable media in town. We decided to publish a newspaper in Tamil and English until Eelanadu could resume publication. No printer in the town was prepared to print our newspaper so we had to rely on old cyclostyle machines to issue our newspaper, Jaffna on Fire out. This was formative experience in political journalism and reporting from a war zone. Several of my friends, fellow students and youths from various parts of the Jaffna peninsula and the East were involved in these activities. Later, several of them became leaders of various Tamil militant groups. It was this moment that catalyzed the nascent Tamil militancy. Most of this group are now dead - killed by state forces in the ensuing war - or targeted in internecine warfare; some of them "disappeared"; a few still live in exile; a handful engaged in the "democratic" mainstream in Sri Lanka. And, I, sitting far from where I was born, lament my inability to name all of them now.

\section{The Apocalypse and After}

2011 marks the release of my eighth collection of poems, kaadaatru (Healing the Forest). ${ }^{5}$ The poems were written mostly during the last stages of the war that ended in May 2009 with the military defeat of the Liberation Tigers of Tamil Eelam (LTTE), once considered by all as an invincible military force. The English translation of Healing the

\footnotetext{
${ }^{5}$ Nagercoil: Kalachuvadu publications, 2012. Some of the poems in this collections are translated into English and included in Kanaganayakam (2011) and Holmström and Ebeling (2012). 214

Indi@logs, Vol 3 2016,pp.211-228, ISSN 2339-8523
} 
Forest does not capture the depth, imagery and ritual undertones of the Tamil title. That's inherent in many a translation and I have no qualms about it.

One of my poems in an earlier collection written in 1999 was "Uuzhi" (Apocalypse). I wasn't expecting an apocalypse, nor had I any premonition of the events of May 2009. Strangely, the images I evoked in "Uuzhi" became a haunting reality. Perhaps, I wanted to write that poem before the Apocalypse, since writing poetry after apocalypse or mass slaughter may not be possible or could be considered barbaric.

But is it?

It is true that Adorno alluded to this when he suggested, "The critique of culture is confronted with the last stage in the dialectic of culture and barbarism: to write a poem after Auschwitz is barbaric, and that corrodes also the knowledge which expresses why it has become impossible to write poetry today" (Adorno.et.al. 1981:34).

However, he didn't maintain that conviction for long - as evident in his subsequent observation that:

[p]erennial suffering has as much right to express itself as the tortured has the right to scream. Therefore, it may have been wrong to say that no poem could be written after Auschwitz. But what is not wrong is the less cultural question if after Auschwitz one can still live... (Adorno, 1973: 363).

Kaadaatru poems were partly provoked by the horrible slaughter of thousands of Tamils in May 2009 and partly the continuation of the poetic strand left hanging in poems such as "Uuzhi" because: 
When people die

To shroud in silence

To withdraw in silence

is not for the poet ${ }^{6}$

In that spirit it could be argued that poetry after apocalypse may be a way to simultaneously transmit and mourn the trauma and unimaginable suffering. The trauma and suffering become even more poignant - amplified and sustained as the perpetrators and the state celebrate our apocalypse as their "victory over terrorism" with ordinary people enthusiastically joining the celebrations.

Kaadaatru is a death ritual performed on the third day after cremation and involves gathering the ashes and bones of the dead. Performing kaadaatru is the beginning of closure. However, the poem sketches the haunting inability to perform kaadaatru and therefore, the impossibility of achieving closure.

Death and numbers have a strange interplay in the Sri Lankan context. For two years the government of Sri Lanka maintained there were no civilian casualties. Initially, the UN did not want to publish casualty figures although it had the information. As the spokesperson for the UN Secretary General said at a press conference, the UN "was trying to save people, not count bodies" (Weiss, 2011: 198). According to Louise Arbour, the former UN Human Rights Commissioner and the current chair of the International Crisis Group (ICG), "the UN withheld information that would have forcefully alerted the world on the impact of civilians of the last chapter of the war" (ibid: 251). Hopefully the reason for this will be explained in the report commissioned by the UN itself to look into its activities in the last stages of war in Sri Lanka.

\footnotetext{
${ }^{6}$ See "The Last Word" in You Cannot Turn Away. 
The UN experts' panel report issued two years after the end of the war estimates that more than 40,000 civilians were killed in the last stages of the war. However, in a submission to the Sri Lankan government appointed "Lessons Learnt and Reconciliation Commission”, the Rt. Rev. Dr. Rayappu Joseph, Catholic Bishop of Mannar, has asked for clarification about the fate of 146,729 people who were unaccounted for between October 2008 and May 2009, based on government statistics and documentary evidence. It may not be that all 146,729 were killed. Many may have escaped. But how do we know? Where's the accountability?

In 2008 the World Food Programme and the government of Sri Lanka had agreed that 350,000 people were living in the war zones. Subsequently, the government began lowering the numbers and in the final phases of the war the government had maintained that only 70,000 people were left in the region, the number parroted by the government media and the Indian minister for Foreign Affairs. ${ }^{7}$ As the UN Expert Panel confirms, the deliberate whittling down of people is to cut down the supply of food and medications to the war zone.

After the war ended, people streamed out of the war zones and more than 300,000 Tamils were interned behind barbed wires and in open spaces giving lie to the "official" government numbers. The photographs of men, women and children behind those barbed wires are chilling evocations of various other internment camps that sprung up in the midst of atrocities over the past century.

The UN Genocide Convention of 1948 defines genocide narrowly and insists upon a very high number of casualties before the mass slaughter of civilians can be classified as genocide in international law. ${ }^{8}$ Genocide is a complex social, political and cultural

\footnotetext{
${ }^{7}$ For a detailed explanation of these numbers see Weiss, 2011:178-179; The Government of Jaffna, Ms. Imelda Sugumar testified at the government appointed Lessons Learnt and reconciliation Commission (LLRC) on November 4, 2010 that there were 360,000 people in the war zones.

${ }^{8}$ The Genocide Convention defines genocide as "any of the following acts committed with intent to destroy, in whole or in part, a national, ethnical, racial or religious group, as such: (a) Killing members of the group; (b) Causing serious bodily or mental harm to members of the group; (c) Deliberately inflicting on the group conditions of life calculated to bring about its physical destruction in whole or in part; (d) Imposing measures intended to prevent births within the group;(e) Forcibly transferring children of the group to another group"
} 
phenomenon that should not be measured by a single set of criteria. However, anthropologically and sociologically speaking what happened on the banks of Nandhikkadal and in the war zones of Vanni in Sri Lanka was clearly genocide; in fact, genocide foretold. ${ }^{9}$

In my view, what transpired in the areas of Nandhikkadal and Mullivaikaal constituted the first genocide of the twenty-first century. This was preceded by numerous genocidal massacres of Tamils in Sri Lanka. As a professional journalist between 1984-1987, I visited the sites of these massacres and reported on several massacres by the Sri Lankan army, navy and air force for the Saturday Review Newspaper in Jaffna.

On a personal note, I lost more than eighty of my friends and relatives in that genocide. Dozens of my relatives and friends were interned. Many of them have not been able to return to their homes and villages.

The international community -whatever that means in the current context - along with the government of Sri Lanka and mainstream media - have readily accepted that "closure" has taken place and the most important task at hand is development and "reconciliation". However, Tamil literary voices that have emerged from the ashes steadfastly refuse to be coerced in the official paradigm of closure, reconciliation and economic development. Numerous collections of poetry and several testimonies of survivors published in Tamil attest to this. ${ }^{10}$ Poetry now has become a vibrant expression and archive for the Tamil experience of genocide. The title, Mullivaaikkalukku-pin (Post-Mullivaaikkal/Poetry after Mullivaikkal) itself is an implicit response to Adorno's earlier statement. A powerful collection of poems by Packiyanathan Ahilan is entitled, Saramakavikal (Poetry of Death and Mourning). In the afterword of the collection the poet says:

\footnotetext{
${ }^{9}$ For a detailed analysis of the anthropology of genocide, see, Alexander Laban Hinton (ed). Annihilating Difference: The Anthropology of Genocide. Berkeley: UCLA Press, 2002. At least one UN official, John Holmes, Humanitarian Affairs Chief of the UN warned in April 2009 that a bloodbath was imminent (quoted in Weiss, 2011:188)

${ }^{10}$ For instance see the following collections of post May 2009 or post Mullivaaikkaal poetry: P. Akilan, Saramakavikal (Poetry of Death and Mourning), Jaffna: 2011; P. Sujanthan, Nilam pirinthavanin kavitha (Poem of a person who was forced from his land); Kutti Revathi (ed).Mullivaaykkaalin pin (Poetry After Mullivaaykkaal), Chennai: Aazhi Publishers, 2010; and A.M.Rashmy, Ee than peyarai marantha pothu ((Fly has forgotton its name), Nagerkoil: kalachuvadu pathippakam, 2011.
} 218

Indi@logs, Vol 3 2016,pp.211-228, ISSN 2339-8523 
A million traumatized minds live in my poetry. Individually and as cumulative heart beat of a population, these poems are entrenched in our collective consciousness... it is impossible to find even a single poem not drenched in blood...these poems have been constantly tossed around by loss, tears and unceasing sorrow (Ahilan, 2011: 49).

In a series of poems entitled Hospital Notes: Vavuniya and Trincomalee, March 2009, Ahilan "records" and "registers" the combined space of mortuary and surgical room in chilling detail:

\section{Corpse Number 183 and Life Number 2}

\section{Lifeless}

Blood is your saree.

Hanging from the vagina

An infant dangles on the placenta

We cut and slap

It cried.

I wrote on the register:

Corpse Number 183

Life number 2 .

A different kind of "closure" is taking place now. That is enclosure, encampment and occupation. The number of military camps and check-points in the North and East are increasing even after the end of the war. According to the military's own statistics, in Jaffna, there are more than 35,000 troops for an estimated 626,329 people, an average of one military personnel for every 18 civilians. ${ }^{11}$ The government has declared 147 army camps in the Tamil areas as permanent. In addition, large swathes of lands in Tamil

${ }^{11}$ See http://www.cimicjaffna.com/Population.php 
majority areas have been converted into High Security Zones (HSZ). These zones are prohibited areas for Tamils. In 2010, the Jaffna peninsula alone had fifteen HSZ. Military officials control day-to-day affairs. ${ }^{12}$ Sinhalese villagers from southern Sri Lanka are being settled in the North and East with the assistance of the security forces - irrevocably altering the patterns of demography in the Tamil areas. The names of Tamil villages are being Sinhalicised and new Buddhist temples are under construction in the Tamil areas. Freedom of expression is routinely trampled upon. The military effectively rules the North and East even without martial law. These are the facts on the ground - all of which are taking place in the name of post war reconciliation and development. The history of occupation from other parts of the world tells us these are naked acts of occupation.

\section{Poems of Genocide}

One of the critical questions posed to me at the various writers' festivals I have attended over the past few years concerns how I 'reconcile' or negotiate my poetry and social sciences. To the surprise of many, I often say that there's no need for "reconciliation" or for complex negotiation.

Are they two irreconcilable domains? Am I conflicted between the two? Although my "application for tenure and promotion" file did not contain a single reference to my poetry or plays, the common thread that runs through various social sciences, humanities and poetry is imagination. After all, the sociological classic by Wright Mills is entitled Sociological Imagination! (Mills,1959)

I believe there's a certain degree of interdependency of poetic, literary, anthropological and sociological imagery. This interdependency is what Ivan Brady (1993) calls the "artful science". The beautiful part of this interdependency is the "in-exactitude" of the interdependent relations. Poetics in this sense is not just a study of literature or poetry but a field and space that extends its cursive tentacles into anthropology and sociology as a way of expanding our understanding and perception of the human condition.

12 For a well documented report on the militarization of the North and East see: http://groundviews.org/2011/11/19/post-war-situation-in-northern-sri-lanka-prospects-for-reconciliation/ 220

Indi@logs, Vol 3 2016,pp.211-228, ISSN 2339-8523 
What takes place when I simultaneously engage in poetry and sociology is, to use a military and occupational metaphor, a kind of "mutual encroachment".

The four poems I offer in English translation chart the trajectory of Occupation, Obliteration and Oppression from 1981-2011. Through these and countless other poems that were written by various other poets in various places of occupation, I invite you to a deeper and profound understanding of genocide, occupation and internment.

While I am comfortable writing plays, and creative non-fiction in English, for reasons unknown to me I always find it impossible to translate my own poetry.

"The Second Sunrise" and "Healing the Forest" were translated by Chelva Kanaganayakam. "Apocalypse” and "Cousin” were translated by Lakshmi Holmstrom.

\section{The Second Sunrise}

On that day

There was no wind

No rising tide,

Even the waves had died.

Sea.

Walking across

Feet sinking in the sand

Again a sunrise.

This time in the South.

What happened?

My town was burned;

My people became faceless;

In my land, my air

In everything, 
The stamp of outsiders.

Hands clasped behind you,

Who did you wait for?

On the clouds

Fire

Has written its tale;

Who waits even now?

From the ashen streets,

Arise and march.

(1981)

\section{Apocalypse}

In our own time we have seen

the Apocalypse. The earth

trembled to the dance of the dead;

bodies burst apart in the wild storm;

darkness shrieked as everything caught fire

inside and out.

The last flood dragged out children and men

and threw them on the flames.

We died in an untimely hour.

Glancing sidelong with our dying eyes

at the helplessness

of those who surrounded us, watching,

we smouldered and smouldered

then rose up in a cloud. of smoke 
Kafka was denied the chance

to set fire to his works.

But Sivaramani burnt hers.

Poetry is destroyed in mid-air.

What others write now

refuses to live.

We have all gone away;

there is no one to tell our story.

Now there is left

only a great land

wounded.

No bird may fly above it

until our return.

(1999)

\section{Cousin}

When my cousin speaks

of enduring six displacements

within nine years

the wrinkles gather and droop

along her face.

The single electric light above

merely deepens the darkness.

A sense of loss prevails

always 
like a lamp keeping vigil

at a dead man's head.

Her words are not punctuated

by sobs; they are taut

with sorrow.

Stirred by old memories

of providing shelter, so often,

to those who escaped the patrolling guards

and travelled secretly, by night,

she glances towards the threshold

from time to time.

She leaves her backdoor open.

When her children, grown up now,

smile at her, in an instant

the legendary milk-ocean materialises.

Her house was on the road

which stretched all the way to the sea

from the front of the temple.

Not a sign of it now.

We went to take a look, in the morning,

accompanied by soldiers

into the high security zone.

Not even a single parrot left

nesting in the holes of palmyra palms 
which still stand upright

although their crowns are shorn.

Upon ripped and fragmented land, men who hold no attachment to it nor kinship, squat, holding weapons.

We retum through the ruins,

the south wind that sprang up yesterday scattering the dust ahead of us, the heat burning us up with fury.

Only headless shadows follow us.

We whose hearts were moved with love

not only for humankind

but also for plants and trees and houses

endure in our times

only the scourge of human arrogance.

(2004)

\section{Healing the Forest}

To heal a still

smoldering land, we went;

no bird in sight.

An empty sky 
above the sparrow-flying

earth.

An ash-covered landless earth

to the edge of that wide expanse;

here, no one knows

how to gather bones.

Yet,

Our libation of milk

the relentless

welling of tears

now mocked with glee

with dance and song

by an estranged foe;

what then is the

way ahead?

To cool the burning heart

there is nothing today.

No witness

for the drop of blood

still not dry.

To claim closure

to dissolve ashes in the sea 
to scatter in the air

to close one's eyes,

there is no air

there is no sea

there is no way

to heal the forest.

(2009)

\section{WORKS CITED}

Adorno, Theodor, Shierry W. Nicholsen \& SAmuel Weber (1981). Prisms. Cambridge, MA: MIT Press.

Adorno, THEODOR (1973). Negative Dialectics [Negative Dialektik.] Translated by E. B. Ashton. London: Routledge and Kegan Paul.

AhILAN, P. ( 2010). Saramakavikal. Jaffna, Sri Lanka: Published by the author.

Civil Military CoOrdination IN JAFFna. "Population Density." Civil Military Coordination in Jaffna. (http://www.cimicjaffna.com/Population.php).

GROUNDVIEWS. "Post-war situation in Northern Sri Lanka and Prospects for Reconciliation."

(http://groundviews.org/2011/11/19/post-war-situation-in-northern-sri-lankaprospects-for-reconciliation/)

Hilton, AleXander (2002). Annihilating Difference: The Anthropology of Genocide. Berkeley: University of California Press.

KNuth, ReBecCA (2003). Libricide: The Regime-Sponsored Destruction of Books and Libraries in the Twentieth Century. Westport, CT: Praeger.

MAITHRi, MALATHI, KUTTI REVATI \& LAKSHMI HolmStRÖM (2012). Wild Girls, Wicked Words: Poems of Malathi Maithri, Salma, Kutti Revathi and Sukirtharani. Bangalore: Sangam House and Kalachuvadu Publications, Nagercoil.

Mills, Wright, C. (1959). The Sociological Imagination. Oxford: Oxford University Press. 
Roberts, Michael (1996). Exploring Confrontations: Sri Lanka: Politics, History and Culture. Amsterdam: Hardwood Academic (Medical, Reference and Social Sciences).

Rudramoorthy, Cheran \& Chelva Kanaganayakam (2011). You Cannot Turn Away: Poems in Tamil. Toronto: TSAR Publications.

UN OfFICE OF THE High COMmissioner FOR Human Rights. "Convention on the Prevention and Punishment of the Crime of Genocide." UN Office of the High Commissioner for Human Rights (http://www.ohchr.org/EN/ProfessionalInterest/Pages/CrimeOfGenocide.aspx)

WARD, GRAHAM (2003). True Religion. Oxford: Blackwell Publications.

Weiss, Gordon (2011). The Cage: The Fight for Sri Lanka and the Last Days of the Tamil Tigers. London: Bodley Head.

CHERAN RUdHRAMOORTHY was born in Alaveddy in Jaffna, Sri Lanka, and began writing poetry at an early age. His two early collections Irandaavathu suriya uthayam (The second sunrise) (1982) and Yaman (God of Death) (1984), together with an anthology of Tamil resistance poems, Maranatthul vaalvom (Amidst death, we live) which he edited in 1985, are all landmarks in contemporary Tamil poetry. Since then he has published several acclaimed poetry collections. He is currently a professor in the Department of Sociology and Anthropology at the University of Windsor, Canada. 